Chapter One

\title{
ARE TOLERATION AND PluRAlism Possible IN JEWISH RELIGION?
}



$\mathrm{J}_{\text {EWISH religion holds certain beliefs about the world that it }}$ takes to be true, including theoretical assumptions and practical obligations. The theoretical assumptions include premises about the Torah's divine origin and the explicit duty of observance incumbent on every Jew. Practical halakhic obligations extend to most if not all spheres of life and, by dint of the theoretical assumptions, compel all members of the Jewish collective. Given these circumstances, can Jewish religion endorse notions of toleration and pluralism toward Jews who do not observe the Torah and the commandments without losing its fundamental meaning?

Two preliminary remarks are in place here. First, a clear distinction is required between my concerns in this book and displays of toleration, or even pluralism, in Halakhah. The saying "these and these are words of the living God" (BT Eruvin $13 \mathrm{~b}$ ), for instance, is often used as proof of Halakhah's support for tolerant or pluralistic attitudes. But this is not necessarily the case, since Jewish religion acknowledges multiplicity only within the system. Halakhah and Jewish religion do not rest on 
theoretical or empirical uniformity, and a diversified spectrum of thought and praxis indeed constitute Jewish religion as a culture of dispute. ${ }^{1}$ Whatever is not part of the system, however, is not considered "words of the living God" but rather a deviation that the halakhic system will not necessarily tolerate and will certainly not approach in pluralistic terms.

The possibility of developing a tolerant and perhaps even pluralistic attitude toward non-Jews posed a fascinating challenge to Jewish tradition, but the difficulties raised by these questions are not comparable to the challenges posed by the attempt to apply these ideas to members of the Jewish collective. Gentiles are not compelled to observe the Torah and the commandments, whereas Jews are bound by these obligations by the very fact that they are Jews. In Tolerance and the Jewish Tradition, Alexander Altman reports the findings of a study on toleration and Jewish tradition and sums them up as ambivalent: "On the one hand, strictness in enforcing the religious discipline of the community, and on the other, a considerable measure of toleration towards the Gentiles." 2 When the other is wholly other, entirely beyond the borders of the Jewish community and Jewish culture, the potential threat to the core of identity is minimal. But when the other is inside a given society and culture, his or her very existence is a menace. No wonder, then, that Jewish tradition was tolerant of strangers.

Can Jewish believers adopt a tolerant or even a pluralistic stance toward non-observant members of the Jewish collective? Can Jewish tradition accept the other within itself, or must it reject these ideas? This is a vital issue, since it also determines the answer to the fundamental question: to what extent can Jewish believers open up to the outside world? Or, to what extent can they participate in a Western community that endorses notions of toleration and pluralism? 
The following discussion will focus on the links between Jewish religion and ideas of toleration and pluralism, and less on the historical question of whether Jewish religion, as an actual historical-cultural phenomenon, displayed toleration toward deviants from halakhic norms or enabled pluralism. A preliminary conceptual analysis of toleration and pluralism is required here because in everyday language, and sometimes in philosophical terminology as well, these concepts appear as similar and sometimes as identical, although they actually represent different ideas.

\section{Toleration and Pluralism}

Toleration - Many scholars have pointed out that toleration is a paradoxical concept, ${ }^{3}$ since it implies that we are willing to bear what we actually reject. Toleration, then, is built on a combination of two opposite trends. We oppose and reject the tolerated approach, but we also enable its existence. In Jay Newman's terms, this is a "split heart" stance. ${ }^{4}$ This "paradoxical conclusion" of rejection and acceptance called toleration rests on several necessary and mutually related assumptions that explain one another.

First, the tolerated stance deviates from what is purportedly the right way. We will not say of a stance we consider worthy that we tolerate it, since we would not reject it in the first place. ${ }^{5}$ The tolerant person, then, is neither a relativist nor a skeptic. Relativism and skepticism do not assume a truth-deviance relationship, since they do not support any outlook and thus cannot justify its rejection either. ${ }^{6}$ Neither one reflects the paradox of tolerance or the split heart. ${ }^{7}$

Evidence of the essential role of the truth-deviation relationship within the toleration idea is the historical context that 
fostered the growth of toleration. The idea of toleration was born in a culture that assumed an objective truth and a monopolistic perception of values, and was neither skeptical nor relativistic. The conceptual meaning of the term "toleration" also reflects this assumption, since toleration is not agreement but rather readiness to bear or suffer what is wrong, despite disagreement. ${ }^{8}$ John Locke, whose Letters Concerning Toleration are among the most significant expressions of the toleration idea, illustrates the link between adherence to a stance and readiness to bear what is perceived as mistaken. ${ }^{9}$

Similarly, speaking of tolerating something we do not care about is pointless. Toleration is predicated on the negative value assigned to the tolerated stance, but not on indifference or obliviousness to it. ${ }^{10}$ The right to be called tolerant applies only when the tolerated attitude conveys deviation from something that tolerant individuals consider worthy. Otherwise, they would not need to exercise discretion to refrain from acting against the tolerated attitude, which is meaningless to them and hence unworthy of their concern.

Second, tolerant individuals can adduce good reasons to substantiate their objection to the tolerated position. Their opposition is not the product of a capricious whim. If tolerant individuals lack justified reasons for opposing the tolerated view, in what sense are they tolerant? Their opposition must have a rational basis. ${ }^{11}$ In everyday language, the concept of toleration is used in a broader sense to include not only opposition based on rational grounds but also on feelings. We say that $X$ is tolerant of her children's dress code or of their favorite music. We expand the use of the concept of toleration to include everything that is unbearable, regardless of the rational grounds that justify this opposition. ${ }^{12}$ This use of the term reflects what could be called "descriptive toleration," which is a psychological portrayal of 
the kindness typical of the person called tolerant. From this description, however, we can hardly draw conclusions about the value of toleration and decide whether it deserves praise or contempt. Descriptive toleration often reflects what Newman calls "moral weakness." ${ }^{13}$ A father unable to deal with his children allows them to do whatever they want. Toleration would hardly be a moral quality or a praiseworthy ethical stance if objection to the tolerated stance were simply a matter of personal taste without any rational grounds.

Third, the tolerant person has good reasons not only to oppose the tolerated stance but also to act against it. This assumption does not follow directly from the previous one, since the right to act against the tolerated view cannot be derived from the existence of rational grounds for opposing it. To justify this right, tolerant individuals require additional assumptions. For instance, a tolerant person could claim a right to act against deviants in order to help them find truth, or to prevent them from harming other members of the community, and so forth. Without believing in the existence of this right, abstention and self-restraint do not denote toleration, because refraining from action could simply follow from the absence of a right to take steps against the tolerated position in the first place. ${ }^{14}$

Fourth, tolerant individuals have counterarguments to substantiate their self-restraint. Without entering into a detailed analysis of the range of reasons that have been suggested in history for the idea of toleration, reasons for toleration can in principle be classified under two main rubrics: utilitarian and value-based. One instance of a value-based consideration could be respect for the other person's autonomy as a free entity. As for utilitarian considerations, their range is extremely broad and spans, inter alia, claims about lack of power to coerce the truth, unsatisfactory results from this coercion, or acknowledgement 
of the tolerated view's instrumental value, which helps to justify the tolerant person's self-perception as such. Thus, for instance, one argument for tolerating Jews adopted in Christian tradition from Augustine to Thomas Aquinas was that Jews should not be forced to convert since their inferior status attests to the truth of Christianity. ${ }^{15}$ The value-based consideration assigns great importance to the dignity of the individual as a person able to choose, who cannot be deprived from this essential characteristic even in the name of truth.

All these grounds for toleration share one common denominator: they rule out the possibility of the tolerated position having any intrinsic value. Tolerant individuals claim that they have the truth but, for various reasons, endorse self-restraint. At times, they do not acknowledge even instrumental value in the tolerated position but refrain from acting against it for utilitarian reasons; at times, they view the tolerated stance as a means to their own ends.

Even when respecting the other and allowing him freedom of thought and action, one need not acknowledge any intrinsic value in his position. One may respect the person's freedom and agree to practice self-restraint without necessarily respecting the tolerated position per se.

Utilitarian and value-based reasons for supporting toleration differ in the level of commitment they command. Utilitarians, for instance, might renounce their commitment to toleration if they believed it useful to oppose the tolerated position. ${ }^{16}$ Toleration advocates who rely on the idea of human dignity would find it hard or probably impossible to relinquish their commitment to toleration since no other consideration could possibly override this idea. If we ascribe moral value to toleration and we praise tolerant individuals, we probably intend the kind of toleration that rests on the idea of human freedom. People who are tolerant 
for utilitarian reasons would not warrant moral acclaim for displays of self-restraint given that, in other circumstances, they might not refrain from intolerant attitudes.

This analysis enables us to separate a prima facie tolerant stance from one of genuine toleration, a distinction that will prove crucial. Individuals often refrain from opposing the other's stance due to paternalistic considerations. Paternalists ascribe features to the tolerated position that enable them to view it as different from what it actually is. For instance, paternalists may claim that, although the tolerated position is founded on a mistake, the people who support it are not responsible for it - they are coerced and are not epistemically liable. At times, paternalists offer an alternative interpretation of the tolerated stance and claim it actually represents their own truth, or at least does not contradict it, even if its supporters are unaware of it. Viewing supporters of the tolerated position in this light enables paternalists to justify their abstention from action. The common denominator of all these paternalistic claims is that they dismiss the "paradox of tolerance" because they do not view the opposite stance as genuine. Paternalists will use analysis to refrain from punishing their opponents, but will not be truly ready to bear the tolerated stance as presented by its supporters. Refraining from punishment is not evidence of a tolerant position because this abstention could be motivated, as noted, by the collapse of the "paradox of tolerance."

Once toleration is characterized through these parameters, the question is: what is its object? What exactly is the tolerant person willing to bear? Ostensibly, toleration could relate to three different objects: views, deeds, and people. Since the tolerant person does not ascribe intrinsic value to either the views or the deeds of the tolerated person, however, it might be more correct to claim that people are the true object of toleration. The tolerant person is ready to tolerate specific people, despite their ideas or deeds. 
The discussion has so far focused on the necessary conditions for making the concept of toleration meaningful. This analysis, however, does not deal with the degree of toleration: How tolerant am I? What is it that I can or may do and I do not? Types of toleration can be classified according to the type of reaction that tolerant people could implement if they were not tolerant, or according to the type of self-restraint they actually practice. The latter leads to a distinction between various levels of weak or strong toleration. ${ }^{17}$ Weak toleration implies that tolerant people do not impose their views on the tolerated person and refrain, for instance, from applying physical force or direct coercion. It could also be broader and include absence of indirect coercion, implying that the tolerant person does not resort to rejection mechanisms that might lead others to change their views. This type of toleration is obviously stronger than lack of physical coercion, since it requires greater restraint. In both these displays of toleration, the tolerant person does not deny the other's freedom of action.

But supporters of this type of toleration have other means of conveying their negation of the other's position while still expressing lesser willingness to tolerate the other. Non-use of these means, which requires great restraint, reflects strong types of toleration. At the first level, tolerant individuals go beyond lack of coercion to argue they are waiving their right to prohibit the social and political expression of the tolerated stance. This type of toleration is evident mainly at the declarative level, in the abstention of proclaiming this prohibition. The three expressions of toleration I have examined so far share a behavioral dimension. The strongest level of toleration, requiring the greatest form of self-restraint, is toleration as a disposition or an attitude of the mind. In this type of toleration, not only does the tolerant individual refrain from banning public displays of the tolerated stance but also avoids deriding it, condemning it, or developing 
negative attitudes toward it. Developing this disposition is easier when toleration is value-based rather than utilitarian, relying on considerations of human dignity and liberty and viewing human beings as free agents whose mistakes should not be scorned.

Another classification distinguishes between various types of toleration according to the public means enabling the tolerant position to exist. In this context, the distinction is between negative and positive toleration. Negative toleration does not interfere with the deeds of others, and neither forbids views nor forces its own. This is not an appropriate reflection of the idea of toleration, since non-interference could simply reflect weakness. Powerless to negate the tolerated stance or coerce others to accept their own, tolerant individuals are deterred from action. In practical terms, this consideration is only temporary and could change with changing circumstances. By contrast, positive toleration represents a view stating that non-interference is insufficient, and imposes obligations on the tolerant person to ensure continued protection of the tolerated position by means of legislation or through other ways. ${ }^{18}$

Pluralism - Since toleration assumes that the tolerated stance is wrong and unjustified, it must contend with the paradox of pluralism and answer the question: why not act against it or, at least, develop a negative disposition toward it? Note that, historically, the idea of toleration played an important role in such cultures as Christianity, which assumed total certainty about its own truth and denied any value to tolerated positions. At first, the idea of toleration reflected the position of the majority vis-àvis the minority and, from the seventeenth century onward, it also came to include deviant individuals. ${ }^{19}$

The idea of pluralism is radically different, both in its historical and sociological contexts, in that it is part of a cultural liberal 
framework that affirms free thought and free action without ensuring the majority view a preferable status. One of the main historical differences is that a tolerant culture is basically a monopolistic religious culture, whereas a pluralistic culture prevails in a liberal-secular environment where religions may even compete with one another. "The pluralistic situation" is one of unbridled competition, without any preferences or advantages. ${ }^{20}$ As Berger describes it: "The pluralistic situation is, above all, a market situation," in which religion is sold as any of the other goods available in the market. ${ }^{21}$ The transition from a tolerant to a pluralistic culture is not sharp and all-inclusive. A pluralistic culture may also include islands of toleration or even of intolerance, indicating it does not accept the market situation in some areas. A prominent instance is the change in the attitude to homosexuality in pluralistic cultures, shifting from intolerance to toleration and from toleration to indifference. This type of relationship is never found in a market situation. A conceptual analysis of pluralism will further understanding of this historical-sociological reality.

Conceptually, pluralism does not reflect a paradox of opposition and acceptance. Pluralists do not "tolerate" different views because they are, as it were, ready to tolerate the people expressing them. Rather, a pluralist considers the other's view valuable and, therefore, respects the person who represents it. Pluralists have views and values to which they attach certainty, and pluralism is not synonymous with an absolute skepticism incapable of substantiating anything. When no stance can be substantiated, "anything goes" and shifting positions is a matter of whim rather than discretion. This state of affairs does not reflect pluralism but lack of care. No stance is preferable to another and, therefore, all positions are irrelevant. ${ }^{22}$

In this sense, a distinction is required between descriptive pluralism, which merely states that people hold different posi- 
tions, and normative pluralism, which is part of a wider, usually liberal, value system. Descriptive pluralism neither justifies nor rejects anything. It describes the factual datum of a multicultural society, which enables this multiplicity out of indifference. By contrast, normative pluralism is not a substitute for rational value allegiance to specific attitudes but reflects a certain commitment that is also rationally substantiated and hence affirms or rejects specific positions. Normative pluralists believe in their own attitudes and preferences and think them well substantiated. They do not agree with the views of others because, logically, their views differ. ${ }^{23}$

Pluralists still differ from tolerant people, however, in that they are not committed to refrain from acting against others since pluralists do not assume any grounds justifying such action in the first place. A pluralist does not view the other's stance as deviant, shameful, or evil, and demanding a reaction. Value preferences do not lead a pluralist to negate the other's views. Unlike tolerant people, pluralists assign to other views the same value they assign to their own, as evident in their respect for the views and the deeds of the other ${ }^{24}$ rather than only for the other's basic human freedom. In other words, value-based toleration may lead a tolerant person to respect someone upholding the tolerated stance, but never its contents. Pluralists, however, respect also the contents of the contrary views. They engage in a genuine discourse with opposite views, not only because they consent to tolerate people and allow their freedom but because they are truly interested in the other's stand and consider it valuable.

Given that pluralists do have value preferences, however, why do they ascribe intrinsic value to other positions? This is the litmus test for distinguishing between two main versions of pluralism, to which I will refer as "weak" and "strong" pluralism. Weak pluralism does not entirely renounce the assumption of one truth 
and the need to find it, but rests on a skeptical position and argues that this truth can only emerge through constant confrontation with contrary views. John Stuart Mill advances this view, as does Karl Popper, who relies on Voltaire. Their shared basic assumption is that human beings are fallible creatures. ${ }^{25}$ Hence, the only way of avoiding mistakes is to contend with contrary views. An open market of attitudes and actions is the best course for human beings, whose cognition is so fragile, to reach truth. Both Mill and Popper reject skepticism and relativism. Mill states: "As mankind improve, the number of doctrines which are no longer disputed or doubted will be constantly on the increase." 26 Mill views the development of humanity as a ceaseless process of rejecting mistaken attitudes and as a "gradual narrowing of the bounds of diversity of opinion." 27 Pluralism, then, is temporary by definition. In an infinite time perspective, it will disappear once truth is revealed. Popper's formulation is not as radical, but he too painstakingly emphasizes the distinction between "fallibilism" and relativism. Human fallibility assumes:

There is such a thing as truth...Fallibilism certainly implies that truth and goodness are often hard to come by, and that we should always be prepared to find that we have made a mistake. On the other hand, fallibilism implies that we can get nearer to the truth or to a good society. ${ }^{28}$

Skepticism, then, is a temporary situation rooted in human reality rather than a metaphysical stance compelling relativism.

This analysis enables us to sharpen the distinction between the weak pluralist and the tolerant person. Tolerant individuals are likely to approach mistaken views as a means for reaching the truth but assume, according to the common definition, that truth has already been found and that they have it, whereas other views are only of instrumental, pedagogical, or epistemic value. By contrast, 
pluralists do not assume the absolute preference of their views over those of the other, since their own views could turn out to be mistaken. Tolerant individuals do not accept the idea of fallibility and, therefore, cannot relate to other views as they relate to their own, whereas pluralists, even when they do have a preferred view, do not claim it is absolutely preferable. In Hare's words, "the best that he has so far discovered." ${ }^{29}$ In Popper's terms, the preferability of the pluralist's position means it has so far not been refuted. The other's position, however, is important for pluralists precisely because they are conscious of human fallibility.

Contrary to weak pluralism, strong pluralism does not assume the existence of one truth, not even ideally. Whereas weak pluralism views the confrontation between opposite views as a means to approximate truth, strong pluralism does not ascribe any instrumental value to contrary positions and considers every stance in the open market of ideas intrinsically valuable, beyond the temporary.

If Voltaire provided the foundation for weak pluralism, Rousseau adopted the strong version of pluralism. The multiplicity of ideas expresses human difference and the value of individuality. ${ }^{30}$ Prominent modern champions of this version are Mill, in Chapter Three of On Liberty, Robert Nozick, and Joseph Raz. Whereas in Chapter Two of On Liberty Mill emphasizes the instrumental value of contrary views, in Chapter Three he sharply reverses his position. The basis for pluralism is now an acknowledgement of the value of individuality as embodied in human differences: "It is not by wearing down into uniformity all that is individual in themselves... that human beings become a noble and beautiful object of contemplation." ${ }^{31}$ Human differences thus create variety and a diversity of lifestyles. Nozick too relies on this justification of pluralism, arguing that we do not know any specific lifestyle equally good for everyone, 
and a utopian society is one that enables all human beings to realize themselves as long as they respect the rights of others. ${ }^{32}$ The recognition of human variety is a descriptive but also a prescriptive statement, which assumes the value of individuality and claims it can only be preserved in a pluralistic worldview. ${ }^{33}$

Joseph Raz proposes another version of strong pluralism. In his view, pluralism is a necessary condition of human autonomy. Autonomous individuals shape their lives and control their own destiny as far as possible, as evident in their choices. But freedom of choice, claims Raz, is not sufficient for autonomy and individuals must be able to choose between contrary options. Autonomy is an empty notion in the absence of options, but the choice must not be only between good and evil and must also involve choice between various possibilities of the good. ${ }^{34}$

Contrary to toleration, then, the common denominator of all versions of pluralism is their adoption of some form of relativism. Weak pluralism is committed mainly to epistemic and hypothetical pluralism, meaning that the truths assumed by the pluralist may emerge as false. Strong pluralism is committed to a particular form of value relativism, meaning there is no one absolute right for an individual, or even for all human beings. But this relativism is limited, since it acknowledges the existence of various forms of the good but also discerns the existence of various forms of evil. Some things are illegitimate and entirely lacking in value. ${ }^{35}$ This conclusion is entirely compatible with the formal characterization of pluralism as a stance within a normative system that distinguishes between forbidden and allowed, worthy and despicable. ${ }^{36}$ The difference between the two versions of pluralism is that, at least in principle, weak pluralism ascribes equal value to legitimate views as an expression of epistemic limitations, whereas strong pluralism ascribes intrinsic value to various versions of the good. 


\section{Jewish Religion and Toleration}

Since toleration developed in a system that assumed value certainty, tolerant individuals had to justify their abstention from action in ways appropriate to their certainties. Indeed, this is how toleration developed. What might be the arguments favoring religious toleration? As noted, Augustine and Thomas Aquinas justified their toleration of the Jews as a conclusion ensuing from Christian certainty. An interesting and highly influential version of the idea of toleration rests on a voluntariness argument, which also draws on religion.

The first one to propose this argument was Sebastian Castellion (1515-1563), who argued that conversion is voluntary by definition and, therefore, cannot be coerced. Jesus never forced anyone to join Christianity, which is essentially endorsed voluntarily. ${ }^{37}$ Castellion was a liberal Protestant thinker who began his career as a friend of Calvin. An elaborate and refined version of this argument was lucidly formulated by Locke in his Letters Concerning Toleration. Locke's argument, as Castellion's before him, rests on the Protestant approach, ${ }^{38}$ suggesting a clear division between church and state.

The state was founded only for one purpose: "The commonwealth seems to me to be a society of men constituted only for the procuring, preserving, and advancing of their own civil interests. Civil interests I call life, liberty, health, and indolence of body." ${ }^{39}$ A church, however, is different: "A church, then, I take to be a voluntary society of men, joining themselves together of their own accord in order to the public worshipping of God in such manner as they judge acceptable to Him, and effectual to the salvation of their souls." 40

Given this distinction between church and state, Locke argues that both must endorse religious toleration. As for the state, Locke raises three arguments: First, 
The care of souls is not committed to the civil magistrate... It is not committed unto him, I say, by God, because it appears not that God has ever given any such authority to one man over another as to compel anyone to his religion. Nor can any such power be vested in the magistrate by the consent of the people, because no man can so far abandon the care of his own salvation as blindly to leave to the choice of any other, whether prince or subject, to prescribe to him what faith or worship he shall embrace. (17)

Second, a state can coerce "but true and saving religion consists in the inward persuasion of the mind, without which nothing can be acceptable to God" (19). In other words, an act performed under coercion has no religious meaning.

Third:

For there being but one truth, one way to heaven, what hope is there that more men would be led into it if they had no rule but the religion of the court and were put under the necessity to quit the light of their own reason, to oppose the dictates of their own consciences, and blindly to resign themselves up to the will of their governors. (21)

Locke points out that, given that the princes of the world have many views on religion, the way to heaven is extremely narrow (21). Should we wish to widen it, on the assumption that it is improper for God to bestow his grace on so few, the basis for attaining redemption for all human beings must be their reason and their conscience rather than a political doctrine.

After divesting political rulers of the power to enforce their authority on matters of faith, Locke shows that the church does not have such power either. As a voluntary association by definition, the church cannot, in his view, rely on coercion. 
Locke does not doubt the truth of Anglican Christianity, nor is his view based on skepticism or relativism. Both Locke and Castellion before him thought that toleration rested on religion and on religious truths: Locke traced a clear link between salvation and voluntarism.

The voluntariness argument substantiates only a weak version of toleration - it simply forbids coercion, and this is indeed all that Locke concluded from it. Furthermore, since the source of Locke's argument is his religious approach, all he is endorsing is negative toleration: one should not interfere to deprive deviants from their freedom, but it does not thereby follow that, within the political framework, one should seek to ensure additional rights for them beyond this minimum requirement. ${ }^{41}$

Can Jewish tradition adopt a tolerant attitude toward nonobservant Jews? If so, can it adopt only the weak version that refrains from coercion or can it endorse stronger versions of toleration? Furthermore, can it embrace only negative toleration or can it also support positive toleration?

Historically, several sources can be pointed out supporting Locke's argument of voluntariness in one way or another. Moses Mendelssohn, who endorses a version of Locke's argument, ${ }^{42}$ draws a distinction between the inter-subjective and the religious realms:

The relations between man and man require action as such... An action beneficial to the public does not cease to be beneficial, even if it is brought about by coercion, whereas a religious action is religious only to the degree to which it is performed voluntarily and with proper intent. ${ }^{43}$

Incipient signs of a measure of support for the claim of voluntariness appear also in halakhic literature. ${ }^{44}$ Thus, for instance, Solomon Kluger writes about coerced observance: 
Concerning matters that the Torah does not command us to impose, we have proof that the Torah wanted observance to be voluntary and never coerced. Hence, if the court did coerce someone, he is not considered to have complied with the commandment, since he did so under duress rather than willingly. ${ }^{45}$

But Kluger does not claim that the Torah forbids coercion altogether or that, in principle, a commandment fulfilled under duress has no value. Instead, he claims that no coercion should be applied on matters that the Torah does not coerce because the very fact that the Torah did not require coercion shows that the value of this particular commandment depends on the individual's will. No general conclusions about coercion follow from this.

The validity of the argument of voluntariness depends on the meaning ascribed to the religious act. Intolerant positions claim that the religious act is intrinsically valuable, regardless of the performer's will, so there is logic to its coercion. By contrast, tolerant positions argue that the value of the commandment is contingent on the performer's intention, so that an act performed under duress has no religious significance. ${ }^{46}$

The argument seems to fit a religion such as Protestantism, which makes voluntarism a cornerstone of its self-perception. It is less relevant, though still possible to some extent, in Judaism, where religious obligations have traditionally been compelled upon all members of the collective.

An alternative basis for weak toleration in Jewish religion assumes its reliance on considerations of result. Coercion is pointless if it does not lead to observance of the commandment or if it violates the conditions required for the performance of the religious act. Meir Simha Hacohen of Dwinsk appears to support this view. Maimonides rules that a man who is legally compelled 
to divorce his wife is coerced to do so until he says, "I consent." Maimonides does know that a coerced divorce is invalid, and thus presumes:

Inasmuch as he desires to be of the Israelites, to abide by all the commandments and to keep away from transgressions - it is only his inclination that has overwhelmed him - once he is lashed until his inclination is weakened and he says "I consent," it is the same as if he had given the get voluntarily. ${ }^{47}$

This source seemingly argues that coercion is allowed only when we know for sure that this person wants to belong to the Jewish collective and resists only because he is overwhelmed by his inclination. Meir Simha Hacohen of Dwinsk indeed claims: "If the court knew for sure that he definitely does not want to [grant a divorce], and it is obvious to them as it is to Heaven that coercing him will be useless and he is willing to die for it, they would forbid laying a hand on him." 48

Prima facie, refraining from coercion in this case means applying a consideration of result. ${ }^{49}$ Yet, the scope for drawing inferences from this source is extremely limited, since we have no proof that considerations of result can be used to justify a wider thesis of weak toleration. Meir Simha Hacohen is drawing a legal inference related to the specific conditions for divorce. A coerced divorce is halakhically invalid, and divorce requires free consent. In this specific realm, then, personal intention is crucial. But does this consideration apply to all other commandments as well?

Elsewhere, however, Meir Simha Hacohen relies more broadly on a result consideration when he excludes the possibility of beating "to death" someone who is unwilling to observe a commandment: "What will we gain? The commandment will not be observed in any event." 50 
Although this source is more precise, it only justifies refraining from direct coercion. Are other forms of coercion, besides beating, also excluded? Is excommunication also forbidden? Reliance on result considerations does not dismiss the option of indirect coercion. For instance, removal and excommunication could be perceived as conveying the collective's attitude toward the deviant. These means may appear necessary so as to deter others, to prevent the damaging effects of deviance on other members of the collective, or to express scorn and revulsion. Abstaining from action in a given situation due to result considerations justifies limited toleration, which could change with the circumstances or due to other result considerations.

Historically, the Jewish collective did not refrain from using a range of means (not necessarily direct coercion) to combat deviance, repeatedly resorting to exclusion and excommunication. Jews sometimes abstained from these measures, not so much out of a desire to refrain from interference in the others' lives but rather due to their fear of the consequence - the irrevocable expulsion of the Jewish deviant from the Jewish people. Sometimes, however, they did impose such sanctions when the consequences were clear. Thus, for instance, Radbaz argues that dispensing with punishment for fear of its effects on the deviant should be dismissed in favor of attention to the potential damage to the community: "Should we fear this [that the person could abandon the Jewish collective], the Torah may have to be repealed since all will know that, due to this fear, we overlook the wrongs of the wicked." 51

Signs of weak toleration are nevertheless present in Jewish tradition and a tolerant approach is conceptually compatible with full commitment to the tradition. This is not true of the strong version of toleration, which refrains from openly forbidding the deviant act. The voluntariness aspect is irrelevant 
here, and we must look for a kind of result consideration. The general talmudic principle "better that they should sin in ignorance than deliberately" (BT Betsah 30a and others), designed to avoid damage to the individual, could serve to justify the strong version - the deviant stance should not be forbidden so as not to turn the deviant into a deliberate transgressor. But whether conclusions drawn from this halakhic principle could be relevant to all prohibitions and in all situations is questionable. Many halakhic sages pointed to the limitations that qualify the implementation of this principle. Some emphasized that this principle applies only when individuals transgress unwittingly. When they wantonly transgress a prohibition, however, "you will rebuke them, curse them, reprimand them, and dismiss them... and even if they do not listen, you will have saved your soul." ${ }^{52}$ Other sages pointed out that this principle does not apply to explicit Torah injunctions. ${ }^{53}$

But even according to sages who assumed that this principle applies to wanton transgressions of Torah injunctions as well, this view denotes indifference to evil rather than its toleration. In the formulation of Moses of Coucy: "A man should not say something that will go unheeded, as is written, 'Do not reprove a scorner, lest he hate thee' [Proverbs 9:8]." ${ }^{54}$ According to this approach, what appears as strong toleration is a classic case of turning the deviant into an evil wrongdoer for whom society is no longer responsible. The halakhic principle relevant to this approach is "stuff the wicked until he dies." The wrongdoer's freedom to act as he pleases and the failure to rebuke him for his transgression denote his removal from the Jewish collective rather than a readiness to tolerate him. ${ }^{55}$

Beyond these caveats, this principle obviously applies only when all members of the collective are committed to the Torah but transgress a specific commandment, be it wantonly or mistakenly. 
When large sections of the collective do not acknowledge the validity of Halakhah, however, its applicability becomes questionable. In these circumstances, this principle could also entail a heavy religious price: abstaining from declaring certain matters forbidden could have serious implications for members of the religious collective, who will conclude that these matters are permitted and will become transgressors. ${ }^{56}$ Hence, although this principle could conceptually be used to justify strong toleration, turning it into a general rule applicable in all circumstances without a more basic transformation of Jewish religion seems unreasonable.

Could Jewish religion adopt the idea of toleration as a mental disposition? I noted above that toleration as a mental disposition is generally based on the value of human freedom. People who err should not be scorned, because their freedom could also lead them to make mistakes. Can someone who is religiously tolerant endorse this view? Can someone for whom religious truth is cardinal prefer the value of human autonomy instead? Religious individuals also believe in the importance of choice, since this is one of the basic assumptions of their religious activity, but the value of choice per se can hardly justify the endorsement of toleration as a disposition.

Believers find it easier to adopt a paternalistic attitude toward deviants, thus precluding feelings of disdain and scorn for them. Much of what passes for "toleration" in the writings of Abraham Yitzhak $\mathrm{Kook}^{57}$ is merely a form of paternalism that does not address the deviant stance as genuine. This paternalism emerges in two forms: ascribing cognitive irresponsibility to deviants, and attempting to understand their "disease." The first is manifest, for instance, in the following statement about the zeitgeist "seducing our young with its many wiles to follow its shameless ways.... They are definitely acting under duress, and we should not, Heaven forbid, judge coercion as we would free will." 58 
Although this approach makes it easier not to despise or scorn others, it also precludes genuine respect for them since it neither recognizes them as cognitively responsible individuals nor does it acknowledge the deviation as a true position. Paternalism, then, although not affected by the paradox of toleration, is by nature limited. Deviants cannot forever be viewed as coerced, unless it is assumed they are cognitively handicapped.

The second form of "toleration" leads Kook to an attempt to understand "the disease of the generation." ${ }^{59}$ According to this analysis, the source of deviance is not the denial of religious truth but the search for a deeper truth and disaffection with religiosity as it is.$^{60}$ The analysis of the deviants' motives may enable us to avoid despising them and may perhaps lead us to respect them, but it rests on the negation of the deviant's self-interpretation of their world and their longings. This negation also reflects the collapse of the paradox of tolerance, since it does not relate to the other's view as genuine.

This type of paternalistic rhetoric may express a tolerant religious approach, which cannot be formulated openly because it hinges on the tension between its halakhic foundation and its readiness for toleration. For toleration as a mental disposition, however, this rhetoric exacts a high price - it does not show respect for the others' freedom and their ability to formulate alternative views. This analysis of R. Kook's view sheds new light on the problems hindering believers from developing a tolerant disposition toward deviance.

All potentially acceptable versions of toleration will, at best, be confined to abstention. Since traditional Jewish religion holds itself absolutely true and valid for every member of the Jewish collective, its believers will hardly engage in a struggle to protect the rights of deviants to realize their ideals. This task can only engage those who view freedom as a cardinal value. 
Tolerant persons are not required to renounce any of their beliefs and, conceptually, traditional Jewish religion can therefore be tolerant. Can it also endorse a pluralistic outlook without becoming self-subversive? Can the believer respect the other as a person as well as the other's views, beliefs, and deeds as having equal and also intrinsic value? Given the believers' perception of Jewish truth as divine, can they respect contrary views without breaching their own religiosity? ${ }^{61}$ Are pluralism and religious authenticity compatible? Endorsing a pluralistic view requires a deep conceptual transformation, a religious revolution enabling the believer not to view the other's stance as deviant. Is such a revolution possible? And if possible, is it worthwhile? Given that the cradle of pluralism is the secularization process, ${ }^{62}$ the question then is: can Jewish religion internalize the ideas of secularization and still remain meaningful to its believers?

\section{Jewish Religion and Pluralism}

These questions need to be examined vis-à-vis the two types of pluralism I proposed, weak and strong. As noted, supporters of weak pluralism assume there is truth and that the stance they uphold is one that has been substantiated in the best way or, at least, has so far not been refuted. These assumptions might be compatible with a religious approach, since religious pluralists willingly acknowledge the limitations of human cognition. In this sense, weak pluralism does not relinquish its clear preference for its own view, and its relativism is mainly cognitive and hypothetical rather than normative. Jewish believers, then, can be pluralists without renouncing their beliefs, but endorsing this view exacts a high price since Jewish beliefs could, at least hypothetically, prove false. The religious pluralist cannot continue 
supporting the belief that, even at a later time, "this Torah will not be changed," as Maimonides states in his Thirteen Principles of Faith. Furthermore, even if this price were reasonable, weak pluralism is incompatible with halakhic language and halakhic deeds. Since this problem is also relevant to strong pluralism, I discuss it below.

Strong pluralism, even though upholding normative relativism, is not necessarily committed to epistemic relativism. The pluralist, therefore, is not necessarily committed to the derogation of the value system that pluralism supports. Conceptually, one may acknowledge the existence of parallel value systems without in principle assuming that they cancel each other out. In this sense, strong pluralists are not committed to the temporariness of their beliefs and their values.

Yet, to enable this kind of pluralism, a fundamental conceptual revolution about the meaning of religious statements is required. Believers supporting strong pluralism must renounce a traditional assumption inconsistent with strong pluralism, namely, that religion is true. Renouncing this option seems impossible in a religious context, since believers cannot agree with the assumption that religion is false. The renunciation, however, could be interpreted to mean that religion is only praxis, and categories of truth and false are irrelevant in its regard. Truth claims about the world, about God, and about crucial events such as the Sinai theophany, are religiously irrelevant. In other words, religion is a value system that neither relies upon nor reflects metaphysical assumptions or factual data that could be translated into truth claims ${ }^{63}$ In John Searle's terms, religion is a constitutive system, ${ }^{64}$ shaping a world of procedures and meanings that do not assume their sense from a specific state of affairs but from the system itself. The religious system formulates norms defined as commandments, and even formulates beliefs applying to these norms, the 
central one being the perception of these norms as God's word at Sinai. In religious terms, the historical fact of the Sinai theophany is not what validates the normative system. If this historical fact is a relevant constitutive rule, it will assume meaning only from the system itself and is, in Searles's terms, an "institutional fact." 65 In this light, the religious fact of the Sinai theophany can be viewed as a kind of judgment and evaluation of halakhic norms. The believer is then commanded to accept that these norms, all or some, are God's word at Sinai, deserving honor and respect as defined by the system itself. According to this outlook, Jewish religion is not founded on statements about the world; rather, like other constitutive systems, it shapes a world of meaning and internal coherence that is not conditioned by outside facts.

As part of this revolution, individuals deciding to embrace Jewish religion seek to actualize a world of norms and meanings articulated by the system, which they consider especially valuable. People's motivations when adopting this system are no different from those driving many to embrace a specific lifestyle: the wish to live within a certain system whose cluster of values they consider worthy of realization, to create a better world for themselves, and so forth.

The religious revolution required to enable strong pluralism relies on the following claims:

(1) Jewish religion is a value system that does not make truth claims about the world or about God but constitutes a value system.

(2) The system's meaning is internal, implying it is not contingent on outside facts. Instead, it emerges as a conclusion from an analysis of the cluster of norms and values through which Jewish religion is constituted.

(3) A person's commitment to religion results from an autonomous decision to realize these particular religious values. 
This conceptual revolution enables the existence of value systems that also have inner value, since none of them formulates truth claims that might prove false. This analysis restricts the meaning of religious statements, thus making room for other value systems that do not make competing truth claims.

Conceptual-theoretical revolutions in religious tradition in general and in Jewish tradition in particular are not new. One of the most basic ways in which traditional societies cope with new challenges is the conceptual transformation of their world of values. This transformation enables the translation of the old world of values into a new conceptual language, without precluding commitment to these values. ${ }^{66}$ Jewish intellectual history abounds with such examples, and Maimonides seems to have prompted the deepest theoretical revolution in traditional culture by creating a new language for the biblical-talmudic world so as to adapt it to the philosophical challenge.

Our revolution does differ from that proposed by Maimonides, since Jewish religion has now become an individual concern. Jewish religion is diverted from the collective-historical context to the individual one; it is a matter of choice or preference, as Berger noted: "Private religiosity, however 'real' it may be to the individuals who adopt it, cannot any longer fulfill the classical task of religion, that of constructing a common world within which all of social life receives ultimate meaning binding on everybody." 67

But even if a conceptual religious revolution were possible and worthwhile, it is not easily compatible with halakhic language and action, which seem to be more rigid. A Jew who does not observe the Torah and the commandments is described in halakhic language as a transgressor, as ignorant of the law, as acting under duress, and so forth. The transgression of certain commandments is considered synonymous with the violation of 
the entire Torah, and breaking the Sabbath in public is particularly important in this context.

The special status of the Sabbath, as Rashi noted, is related to its theological meaning: "The Sabbath transgressor denies His acts, and falsely attests that the Holy One, blessed be He, did not rest on the Sabbath." 68 If this is the status of the Sabbath, the conceptual revolution faces a hard challenge because this status points to the presence of a deep metaphysical sediment in the halakhic realm. No less important, however, is the halakhic implication that follows. A mainstream halakhic tradition, stretching from Halakhot Gedolot ${ }^{69}$ through the literature of the early authorities ${ }^{70}$ and up to modern halakhic literature ${ }^{71}$ speaks of Sabbath breakers in public as complete idolaters no longer included in the Jewish collective. ${ }^{72}$ Various sages, however, developed a more tolerant attitude toward Sabbath breakers for other reasons. Some relied on considerations of result, claiming that an approach that views public Sabbath breakers as Gentiles would lead them to abandon the Jewish people. Others relied on a sociological consideration, arguing that the precondition for breaking the Sabbath in public is the existence of a society that observes the Sabbath. However:

In our times, they are not called public Sabbath breakers because this is what most people do. When most Jews are not guilty, the few who dare to transgress are denying the Torah, committing an abomination, and excluding themselves from the Jewish people. Unfortunately, however, when most Jews are transgressors, the individual believes this is not such a serious offense and one need not hide. ${ }^{73}$

The transgressor's intention is thus a necessary condition for determining the seriousness of the offence. In light of secula- 
rization, the Sabbath breaker has no consciousness of being a sinner and, therefore, is not in the category of a public Sabbath breaker.

These considerations might, at best, substantiate weak toleration, but they cannot justify pluralism. Pluralism contradicts Halakhah's basic assumption, which holds that all Jews are compelled to observe the Torah and the commandments by virtue of the Sinai covenant, making pluralism an extremely difficult position to sustain in religious terms. First, pluralism is committed to a deep religious-conceptual revolution. Second, this revolution is not sufficient either, since Halakhah might be compatible with toleration but not with pluralism. In other words, the maximum possible is a pluralistic consciousness and halakhic toleration.

Is pluralism then entirely incompatible with Jewish religion? Halakhah is indeed hard to integrate with a pluralistic stance, but a religious revolution is not a negligible feat even if it cannot be directly translated into practice. It creates a new consciousness that could be significant in and of itself and, indirectly, could also contribute to practical trends. Even if unable to foster a pluralistic Halakhah, it might promote tolerant trends that will somehow progress toward pluralism. The religious pluralist may be doomed to live in permanent tension, fluctuating between a religious and pluralist pole on the one hand and, on the other, a halakhic pole that, at best, will be tolerant. This tension is a good illustration of the pluralist's participation in two communities - a Western community that endorses pluralism and a halakhic Jewish community unreservedly committed to its own directives. Membership in these two communities at times leads to a deep value conflict. Yet, as I have shown elsewhere, ${ }^{74}$ affirming a conflict between two different value systems is, in logical terms, a measure of the deep commitment felt toward 
both. The conflict, then, is the quintessential affirmation of membership in both communities.

Finally, do religious believers have any reason for embracing religious pluralism despite the heavy religious price it exacts? The answer to this question is highly complex. Good religious reasons can be adduced for doing nothing at all, due to the religious concessions expected from tradition, to the ultimately conflictual effects of any action, and to its future implications for life in general and for religious truths in particular. A believer choosing to remain within a traditional framework could hardly accept arguments that might lead to its erosion and would have no reason to adopt a pluralistic outlook. The question is only relevant to a believer leaning toward pluralism - can rational justifications be found for this inclination? The reasons justifying the pluralistic believer's preferences will not make traditional believers change their minds, but are extremely valuable to the pluralist. These reasons are a conscious reconstruction of the pluralistic believer's world, an explication of the first datum in the pluralist's consciousness. In other words, these reasons provide pluralistic believers a theoretical foundation for the religious world they have long inhabited.

A serious attempt to contend with the questions raised by pluralism is to be favored on three counts. First, pluralism poses a serious challenge to traditional believers who see themselves as members of Western liberal societies by compelling them to examine the extent to which they can negate the intrinsic value of the other's world without hindering this membership. Second, concerning many public and value-based questions, believers who have opened up to the world endorse a pluralistic outlook. If they translate this outlook into actual behavior, they have to meet the theoretical challenge of formulating a pluralistic religious world view. Third, one interesting reaction of modern 
believers striving to preserve their religious beliefs and values is a perception of the religious world as a unique type of religious experience. Several scholars have indicated that religiosity in the modern world is no longer based on a rational-metaphysical cognition but on a personal subjective experience. This experience is an autonomous realm that cannot be exhausted or understood through any other context, and is thus the starting point of the religious domain. ${ }^{75}$ The crucial role of subjectivity in human existence paves the way for a renewed justification of religion through the acknowledgement of subjective religious experience, which believers view as an autonomous realm out of which they relate to and interpret the world.$^{76}$ Adopting this approach compels what Hick called the "intellectual Golden Rule": ${ }^{77}$ believers must allow others what they take for themselves, meaning they must recognize the justified value of the experience of others who are not like them. ${ }^{78}$

In sum, this chapter was an attempt to offer an initial outline for a discussion of the possibility of toleration and pluralism within a religious outlook. My conclusion is that, conceptually, toleration is an easier stance for the believer to accept and might be compatible with a traditional world view. Endorsing pluralism requires a religious revolution and exacts a heavy religious price, and yet, it is pluralism rather than toleration that challenges believers living in our modern-liberal world. 


\section{Notes}

1 For an analysis of halakhic pluralism and its borders see my book, The Open Canon: On the Meaning of Halakhic Discourse, trans. Batya Stein (London: Continuum, 2007).

2 Alexander Altman, Tolerance and the Jewish Tradition (London: The Robert Waley Cohen Memorial Lecture - Council of Christians and Jews, 1957), 8. A classic expression of the halakhic tendency to coerce all members of the Jewish collective is evident in the work of Raphael Cohen, rabbi of Altona-Hamburg, a prominent eighteenth-century halakhic scholar: "The foundation of the Torah and the commandments is to coerce and punish transgressors... and whoever has seen the lights of Torah in his lifetime knows that the...foundation of the Torah and the commandment is built upon coercion" (Raphael Cohen, Da'at Kedoshim [Altona: Judah Brothers, 1797), 48a.

3 See D. D. Raphael, "The Intolerable," in Justifying Toleration: Conceptual and Historical Perspectives, ed. Susan Mendus (Cambridge: Cambridge University Press, 1988), 140; Preston King, Toleration (London: George Allen and Unwin, 1976), 29ff.

4 Jay Newman, "The Idea of Religious Tolerance," American Philosophical Quarterly 15 (1978), 187.

5 Compare Jeremy Waldron, "Locke: Toleration and the Rationality of Persecution," in John Locke: A Letter Concerning Toleration in Focus 
(New York: Routledge, 1991), 100. Waldron indicates (121, n. 8) that Joseph Raz does not agree with this. As will be shown, even though Raz uses the term "toleration" he is referring to pluralism, which explains why he does not endorse this assumption.

6 King, Toleration, 25-26.

7 Newman, "The Idea of Religious Tolerance," 189.

8 The claim that the idea of toleration was born in a climate rejecting the concept of objective value is thus groundless. See, for instance, Roberto Mangabeira Unger, Knowledge and Politics (New York: Free Press, 1984), 76.

9 See Waldron, "Locke: Toleration," 105-106.

10 Some hold that caring is the opposite of toleration, as opposed to others who hold that the opposite of toleration is intolerance rather than indifference, since caring is a pre-condition of toleration but is not identical with it. See Peter Nicholson, "Toleration as a Moral Ideal," in Aspects of Toleration, ed. John Horton and Susan Mendus (London: Methuen, 1985), 162.

11 This formulation endorses Nicholson's view. See ibid., 160.

12 See Mary Warnock, "The Limits of Toleration," in On Toleration, ed. Susan Mendus and David Edwards (Oxford: Clarendon Press, 1987), 125-126.

13 Newman, "The Idea of Religious Tolerance," 194.

14 Nicholson further claims in "Toleration as a Moral Ideal" that tolerant people must have the power to act against the tolerated position. Assuming otherwise means they are forced to admit it exists without genuinely allowing it, since the tolerated stance does not depend on them at all. In the absence of such power, one can only speak of toleration in the limited sense of claiming that, if they had power, they would nevertheless refrain from exercising it (161). This assumption fits the definition of toleration as a behavioral stance, restraining the power to act, but does not apply to toleration as a mental stance or a disposition toward the tolerated attitude, where the power to act is irrelevant. The tolerant person will be one who does not reject, derive, curse, or assume a similar attitude toward the tolerated position, without considering the question of power. For a discussion of these types of toleration, see below. 
For an analysis of Augustine and Thomas Aquinas and their implications for a tolerant attitude toward Jews, see Alex Bein, The Jewish Question: Biography of a World Problem, trans. Harry Zohn (New York: Herzl Press, 1990), chs. 2 and 3.

16 For a detailed critique of consequential considerations see Albert Weale, "Toleration, Individual Differences, and Respect for Persons," in Aspects of Toleration, ed. John Horton and Susan Mendus (London: Methuen, 1985), 19-23.

17 Warnock, who also differentiates between various types of toleration, chose the first option I suggested, so that what I call weak toleration is for her strong toleration (Warnock, "The Limits of Toleration," 126-127). I prefer the second option since the value of toleration is determined precisely by the level of self-restraint it reflects.

18 On this distinction, see Lord Scarman, "Toleration and the Law," in On Toleration, ed. Susan Mendus and David Edwards (Oxford: Clarendon Press, 1987), 49.

19 Locke's Letters Concerning Toleration are good examples of this turnabout. Locke does not necessarily refer to a tolerated minority group but to deviant individuals.

20 Peter Berger, The Sacred Canopy (New York: Anchor Books, 1990), 135. See also John Rawls, A Theory of Justice (Cambridge: Harvard University Press, 1971), 28-29; Charles E. Larmore, Patterns of Moral Complexity (Cambridge: Cambridge University Press, 1987), 22-23; Michael Sandel, Liberalism and the Limits of Justice (Cambridge: Cambridge University Press, 1982), 1.

John Kekes is deeply critical of the link between liberalism and pluralism. His main claim is that, whereas the pluralist cannot be committed to a specific system of values that overrides all others, liberalism in its various versions does evince this type of commitment. See John Kekes, The Morality of Pluralism (Princeton, NJ: Princeton University Press, 1993), 199-217. Kekes' critique is unpersuasive because his claims about pluralism are far too strong. To assume that pluralists hold that in all situations and concerning all issues there are no overriding values is implausible. Indeed, Kekes himself acknowledges the existence of unjustified options or ways of implementation (ibid., 14), in which case a liberal world 
view could be seen as the minimum condition for removing them. But even if Kekes is right, the historical fact is that pluralism did indeed originate in a secular-liberal culture, and Kekes' analysis does not satisfactorily account for this.

21 Berger, The Sacred Canopy, 138.

22 Compare Søren Kierkegaard, Either/Or, vol. 1, trans. Howard V. Hong and Edna Hong (Princeton, NJ: Princeton University Press, 1987), 38-40. For an incisive critique of American culture as indifferent, see Allan Bloom, The Closing of the American Mind (New York: Simon and Schuster, 1987), Part Two.

23 See Richard M. Hare, Freedom and Reason (Oxford: Clarendon Press, 1982), 178.

24 Ibid.

25 John Stuart Mill, On Liberty (Hammonsdworth, England: Penguin, 1984), 77; Karl Popper, "Toleration and Intellectual Responsibility," in On Toleration, ed. Susan Mendus and David Edwards (Oxford: Clarendon Press, 1987), 18.

26 Mill, On Liberty, 106.

27 Ibid.

28 Popper, "Toleration and Intellectual Responsibility," 25.

29 Hare, Freedom and Reason, 180.

30 Nicholas Dent, "Rousseau and Respect for Others," in Justifying Toleration: Conceptual and Historical Perspectives, ed. Susan Mendus (Cambridge: Cambridge University Press, 1988).

31 Mill, On Liberty, 127.

32 Robert Nozick, Anarchy, State, and Utopia (Oxford: Basil Blackwell, 1974), 310.

33 This is the solution to the naturalistic fallacy in this version of pluralism, pointed out in Milton Fisk, Ethics and Society: A Marxist Interpretation of Value (New York: New York University Press, 1980), 87.

34 See Joseph Raz, "Autonomy, Toleration, and the Harm Principle," in Justifying Toleration: Conceptual and Historical Perspectives, ed. Susan Mendus (Cambridge: Cambridge University Press, 1988) 156-157. Compare also Stanley I. Benn, "Freedom, Autonomy, and the Concept of a Person," Proceedings of the Aristotelian Society 76 (1975-1976): 123-128. 
There is a clear link between the value of individuality that Mill and Nozick emphasize, and the value of human autonomy that Raz emphasizes. Autonomy in the sense of shaping and organizing life based on a personal decision is a classic expression of individuality, though the versions proposed by Mill and Nozick are slightly different from that offered by Raz. Raz sees the various options as competing alternatives that are a condition of autonomy, whereas Mill and Nozick are not committed to that view. They do not see these options as mutually competing necessarily but as reflecting, above all, the various possibilities of different people.

As noted, according to Raz, the condition of autonomy is a choice between good options, and not only between good and bad options. For additional distinctions between pluralism and relativism, see Kekes, The Morality of Pluralism, 8, 14, 31-32, 46-47.

Nevertheless, the relativism assumed by Nozick is broader than that assumed by Raz because Nozick's relativism relies on the variety and multiplicity of human experience.

37 For an analysis of his position, see King, Toleration, 78-80. See Waldron, "Locke: Toleration and the Rationality of Persecution," 117.

39 John Locke, A Letter Concerning Toleration, ed. Mario Montuori (Hague: Martinus Nijhoff, 1963), 15.

40 Ibid., 23.

${ }^{41}$ See also Waldron, "Locke: Toleration and the Rationality of Persecution," 111-115.

42 On the relationship between Mendelssohn and Locke, see Julius Guttmann, Religion and Science (in Hebrew) (Jerusalem: Magnes Press, 1955), 212-213; for an analysis of Mendelssohn's toleration see Jacob Katz, Exclusiveness and Tolerance: Studies in Jewish-Gentile Relations in Medieval and Modern Times (Oxford: Oxford University Press, 1961), ch. 14.

43 Moses Mendelssohn, Jerusalem: On Religious Power and Judaism, trans. Allan Arkush (Hanover: University Press of New England-Brandeis University Press, 1983), 72.

44 Michael Zvi Nehorai, "Can a Religious Deed Be Coerced?" (in Hebrew), in Between Authority and Autonomy in Jewish Tradition, ed. 
Avi Sagi and Zeev Safrai (Tel Aviv: Hakibbutz Hameuchad, 1997), 364-381. Nehorai argues that Halakhah sees no basis or justification for coercing a religious act. Although his view is unquestionably one-sided, evidence definitely points to sources that support, or at least come close to, a tolerant stance.

45 Solomon Kluger, Hokhmat Shlomo on Shulkhan Arukh, Hoshen Mishpat, 107a. This commentary appears in all the standard editions of Joseph Caro's code, the Shulkhan Arukh.

46 See Nehorai, "Can a Religious Deed Be Coerced?." See also Jacob Levinger, From Routine to Renewal: Pointers in Contemporary Jewish Thought (in Hebrew) (Jerusalem: De'ot, 1973), ch. 9. Levinger holds that this tension is evident in the contrast between the positions of Judah Halevi and Bahya ibn Pakuda. Judah Halevi attaches metaphysical value to the actual performance of the commandments regardless of subjective intentions, whereas Bahya holds that the religious act is meaningless unless performed intentionally.

47 The Code of Maimonides, The Book of Women, trans. Isaac Klein (New Haven: Yale University Press, 1972), Laws of Divorce 2: 20.

48 Meir Simha Hacohen of Dwinsk, Or Sameah, ad locum. Note the changes in the interpretation of Maimonides. Raphael Cohen views Maimonides' statement as a basis for the possibility of coercion and, in clear contrast to Mendelssohn's view, although familiar with it, he concludes from Maimonides: "When a Jew observes a commandment, even if under duress, he will be seen as having done so willingly, because coercing him is only meant to weaken his evil inclination" (Da'at Kedoshim, 42a). On Cohen and his attitude to Mendelssohn see Jacob Katz, Halakhah in Straits: Obstacles in Orthodoxy at its Inception (in Hebrew) (Jerusalem: Magnes Press, 1992), 21-42.

49 As Levinger and Nehorai indeed attempted to conclude.

50 Or Sameah on Maimonides, Laws of Kings 4: 3.

51 David b. Zimra (known as Radbaz), Responsa (Bnei Berak, 1975), 1: 187.

52 Shlomo b. Yitzhak (known as Rashi), Responsa (Bnei-Berak: 1980), \#20.

53 Asheri, Responsa (Jerusalem: Or Hamizrah, 1994), 28: 13; Isachar Ber Illenburg, Sefer Beer Sheva (Jerusalem, 1982), \#22, and others. 
Moses of Coucy. Sefer Mitzvot Gadol (Bnei Berak, 1988), end of commandment 11.

55 For an analysis of the principle "stuff the wicked until he dies" see Yosef Ahituv, "'Stuff the Wicked Until He Dies': Refraining from Saving a Sinner" (in Hebrew), Tehumin 9 (1985): 156-170; Herzl Henkin, "Better For Them To Be Mistaken Than Wanton" (in Hebrew), Tehumin 2 (1981), 272-280.

56 Shitah Mekubetset (BT Betsah 30a) cites the view of Yom-Tov ben Avraham Ishbili (known as Ritba), ascribed to "French sages, among them the Maharam of Rottenburg." According to this view, "this idea ['better for them to be mistaken'] was meant only for their time [the talmudic period], but in our generation, which is more lenient, we ought to place a fence on the Torah, even if it is rabbinical, and we should fine them until they no longer transgress, whether mistakenly or wantonly." This is also the view of Yitzhak Abulafia, who claims: "And if they [the French tradition quoted above] said so about their own ancient times, what should we say in our bad days, so far removed from the early generations, of blessed memory... Surely if we say 'Let them be and so forth,' the Torah will disappear altogether... even more so since have no power to chastise them, fine them, and force them to mend their ways. Even so, we must rebuke them and abide by what our law requires" (Penei Yitzhak, Part 5 [Izmir, 1898], 4a-b)." Zvi Zohar, Tradition and Change (in Hebrew) (Jerusalem: Ben Zvi Institute, 1993) notes that Abulafia "tends to rely on a single Ashkenazi source against a majority of the sages" (224, n. 88). Even if true, however, the key question is not the source that the halakhist relies upon but the halakhic policy that should be applied in a reality of increasing secularism.

57 For an analysis of R. Kook's tolerant thought see Benjamin IshShalom, "Tolerance and its Theoretical Basis in the Teaching of Rabbi Kook" (in Hebrew), Daat 20 (1988): 151-168; Zvi Yaron, The Philosophy of Rabbi Kook, trans. Avner Tomaschoff (Jerusalem: WZO, 1991).

58 Abraham Yitzhak Kook, Iggerot ha-Rayha (in Hebrew) (Jerusalem: Mosad Harav Kook, 1962), 171.

59 See "Ha-Dor" [The Generation] in Abraham Yitzhak Kook, Eder HaYakar v'Ikvei Ha'Tson (Jerusalem: Mosad Harav Kook, 1972), 109. 
60 See Benjamin Efrati, The Defense in Rav Kook's Philosophy (in Hebrew) (Jerusalem: Mosad Harav Kook, 1959), 20-27; Benjamin Ish-Shalom, Rav Avraham Yitzhak Ha-Cohen Kook: Between Rationalism and Mysticism (Albany: SUNY Press, 1993), 133-134.

61 Compare Mordechai Piron, "The Principles of Religion v. the Perceptions of Toleration" (in Hebrew), Mahanayim 5 (May 1993), 51.

62 Berger, The Sacred Canopy, ch. 6.

63 Ahituv refers to this trend as "concept minimization and reduction." In his view, "the 'non-fundamentalist' Jew will try as far as possible to minimize religious-halakhic and theoretical concepts, so as to be able to accept them without a need for ontological-metaphysical assumptions." See Yosef Ahituv, On the Edge of Change: A Study of Contemporary Jewish Meanings (in Hebrew) (Jerusalem: Ministry of Education, 1995), 59. As noted in previous chapters, instances of this trend in Jewish philosophy can be found in the thought of Yeshayahyu Leibowitz and Eliezer Goldman.

64 John Searle, Speech Acts (Cambridge: Cambridge University Press, 1980), 33-42.

65 On the distinction between "institutional fact" and "brute fact," see ibid., 50-53. The obvious link between Searle and Leibowitz is pointed out in Asa Kasher, "Paradox, Question Mark" (in Hebrew), Iyyun 26 (1976): 236-241.

66 On three reactions of traditional societies to new challenges, including transformation, see Samuel N. Eisenstadt, Tradition, Change, and Modernity (Malabar, Fla.: Robert Krieger, 1983), ch. 14.

67 Berger, The Sacred Canopy, 133-134.

68 Rashi, BT Hulin 5a, s.v. ilema mumar.

69 Sefer Halakhot Gedolot, ed. Azriel Hildesheimer (Berlin, 1888), 516.

70 See, for instance, Abraham b. Yitzhak of Narbonne, Sefer haEshkol, ed. Shalom and Hanokh Albeck (Jerusalem, 1984), Part 2, 105; R. Yitzhak bar Sheshet Barfat (known as Ribash), Responsa (Jerusalem: Machon Yerushalayim, 1993), \#4, Beth Yosef, Yoreh Deah, 119 and others.

71 See, for instance, R. Moshe Sofer (known as Hatam Sofer), Responsa (Jerusalem, 1970-1972), Part 3, Deletions, \# 195; Rabbi Moshe Schick (known as Maharam Schick), Responsa (Jerusalem, 1984), Hoshen 
Mishpat, \# 61; Hayyim Elazar Shapira, Responsa Minhat Eliezer (New York, 1958), Part 1, \# 74.

72 Ribash, Responsa, \#4, Beth Yosef, Yoreh Deah, 119; Maharam Schick, Responsa, Hoshen Mishpat, \# 61.

73 David Zvi Hoffman, Responsa Melamed Leho'il (Frankfurt: Hermon, 1926-32), 1: \#29.

74 See my article, "The Suspension of the Ethical and the Religious Meaning of Ethics in Kierkegaard's Thought," International Journal for Philosophy and Religion, 32 (1992): 83-103.

75 Peter Berger refers to this approach as inductive. See Peter L. Berger, The Heretical Imperative: Contemporary Possibilities of Religious Affirmation (New York: Anchor Press, 1979), ch. 5. See also John Hick, Problems of Religious Pluralism (New York: St. Martin's Press, 1985), 16-27.

76 Compare, John Hick An Interpretation of Religion: Human Responses to the Transcendent (New Haven: Yale University Press, 1989), ch. 13.

77 Ibid., 235.

78 Note that Hick devoted a great deal of attention to the question of inter-religious pluralism. In an earlier work, God Has Many Names (Philadelphia: Westminster Press, 1982), Hick founded inter-religious pluralism on the decisive role of the person's past in the creation of the religious experience (ch. 6), but did not deal with the implications of this idea for developing a pluralistic stance toward the secular world. Resorting to the subjective basis of the religious experience was a response to the secular world, which had made subjectivity and autonomy its central ideas. But why limit the application of this strategy to the justification of inter-religious pluralism? Its logic requires acknowledging secular experience too as intrinsically valuable, lest we lose the possibility of founding the religious experience on the individual's subjective past. 